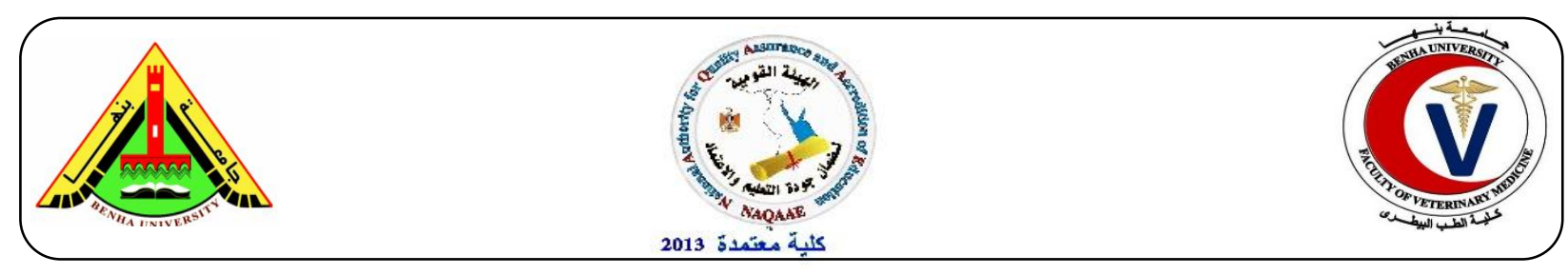

\title{
Evaluation of L-carnitine in the treatment of experimentally induced hypomagnesemia in sheep
}

\author{
Mahmoud A. Y. Helal ${ }^{1, *}$, Abdel-Ghany Hefnawy ${ }^{1}$, Seham Y. Abokora ${ }^{2}$, Ahmed S. Koptan ${ }^{1}$ \\ 1. Department of animal medicine, faculty of veterinary medicine, Benha university -Egypt \\ 2. Department of pharmacology, faculty of veterinary medicine, Benha university, Egypt \\ *Corresponding author: Mahmoud A.Y. Helal E mail: mahmoudatef75@yahoo.com \\ Cell phone: 01096714394. Postal Code:13736
}

\section{A B S T R A C T}

The aim of this study was to evaluate the role of L-carnitine in the treatment of experimentally induced hypomagnesemia in sheep. This study was carried out on 10 ossimi rams aged 10-12 months old with an average live weight of $35 \pm 1.1 \mathrm{~kg}$ that were used for experimental induction of hypomagnesemia. Rams with induced hypomagnesaemia were divided into two groups according to the line of treatment. The first group $(n=5)$ was treated by the traditional treatment alone while the second group $(n=5)$ was treated by the traditional treatment in addition to L-carnitine $(20 \mathrm{mg} / \mathrm{kg} \mathrm{I} / \mathrm{V})$. The symptoms of hypomagnesemia appeared gradually until complete appearance of symptoms at day 28 post induction. There was significant decrease $(\mathrm{P}<0.05)$ in serum magnesium $(\mathrm{Mg})$, calcium $(\mathrm{Ca})$, glucose and parathyroid hormone $(\mathrm{PTH})$ in experimentally induced hypomagnesemic rams. However, there were significant increase $(\mathrm{P}<0.05)$ in serum sodium $(\mathrm{Na})$, potassium $(\mathrm{K})$, urea, creatinine, cortisol, creatine phosphokinase (CPK) and troponin I (cTnI) in experimentally induced hypomagnesemic rams. Treatment of hypomagnesemia with traditional treatment and L-carnitine resulted in significant elevation $(\mathrm{P}<0.05)$ of serum $\mathrm{Mg}, \mathrm{Ca}$, glucose and PTH in hypomagnesemic rams than traditional treatment only. However, there were significant reduction $(\mathrm{P}<0.05)$ in serum $\mathrm{K}$, urea, $\mathrm{CPK}$ and $\mathrm{cTnI}$ than traditional treatment only at 24 hour after treatment. Based on the results of this study we concluded that the addition of L-carnitine to the traditional treatment of hypomagnesaemia in sheep is effective and produced earlier and more pronounced recovery.

Key words: Experimental, hypomagnesemia, L-carnitine, sheep, treatment

\section{INTRODUCTION}

Magnesium (Mg), the fourth most common cation in the body which is a cofactor in more than 300 cellular enzymatic systems and has a key role in cellular metabolism (Baig et al., 2012). Hypomagnesemic tetany is a highly fatal disease affecting all ruminants of all ages and of both sexes' certain conditions, such as fasting or reduced feed intake, may result in tetany or paresis (Hoff et al., 1993). Morbidity is usually low, but can exceed $25 \%$ under some conditions. Low serum $\mathrm{Mg}$ concentration is characteristic of the disease, 
and frequently serum $\mathrm{Ca}$ concentration is concurrently decreased. (Robert et al., 1988.)

The etiology of hypomagnesemia is complex due to numerous interacting factors influencing $\mathrm{Mg}$ content in the diet, as well as its availability and absorption (Robson et al., 1997). The relationship of $\mathrm{K}, \mathrm{Ca}$, and $\mathrm{Mg}$ in forage is an important factor in the development of hypomagnesemia. Heavy K fertilization can cause hypomagnesemia even when $\mathrm{Ca}$ and $\mathrm{Mg}$ levels are within the normal range (Grunes et al., 1984; Schonewille et al., 2000). Potassium ingestion by ruminants may be an enhancement of the urinary excretion of $\mathrm{Mg}$, the major effect on $\mathrm{Mg}$ metabolism is a substantial reduction of absorption of $\mathrm{Mg}$ from the reticulorumen (Tomas and Potter, 1976; Schonewille et al., 2000)

The classical acute (tetanic) form of hypomagnesaemia is due to the critical role that magnesium plays in neuromuscular transmission. Clinical signs initially include depression and dullness, and later progress to stiffness, excitability, tremors, chewing, and hypersalivation, blinking of the third eyelid, twitching of the pinnae (ear flapping), collapse, tetanic muscle spasms, coma and death. (Foster et al., 2007). Ghanem (2013) recorded elevation of $\mathrm{K}$, aspartate aminotransferase (AST), alkaline phosphatase (ALP), CPK and lactate dehydrogenase (LDH) and urea in hypomagnesemic calves. However, significant reduction in serum $\mathrm{Ca}$, glucose and PTH was observed.

The traditional treatment of hypomagnesemia in ruminants includes administration of $\mathrm{Mg}$ and $\mathrm{Ca}$ salts, separately or as a combined solution (Foster et al., 2007; Elliott, 2009; Ghanem, 2013).
L-carnitine is the form of amino acid Lysine and Methionin which plays an important role in transforming of free fatty acids into energy. It forms free fatty acid esters and causes oxidation of free fatty acids in mitochondria. L-carnitine has a number of functions, such as transforming fatty acids into energy, preventing ketosis, carrying ATP from mitochondria to cytosole, (Haemeyer et al., 1997; Harmeyer 2001)

L-carnitine supplementation has beneficial effects on animal performance by enhancing resistance to metabolic diseases, preventing some diseases, strengthening immune system, and playing an important role in metabolic and physiological processes (Fathi and Farahzadi 2014). L-carnitine supplementation increased serum $\mathrm{Ca}$ concentrations in patients with renal diseases (Mercadal et al., 2018). Moreover, administration of L-carnitine in resulted in elevation of plasma glucose concentration and reduction of blood urea concentration (Chapa et al., 2001, Mercadal et al., 2018). Parenteral administration of L-carnitine was used a protective measure against pregnancy toxemia via increasing serum glucose concentration in goats (Kaçar et al., 2010).

Thus the aim of this study is to evaluate the role of $\mathrm{L}$ - carnitine as a supportive treatment in experimentally induced hypomagnesemia in sheep.

\section{Materials and Methods}

a. Induction of hypomagnesemia

Ten apparently healthy ossimi rams aged 10-12 months old with an average live weight of $35 \pm 1.1 \mathrm{~kg}$ were used for experimental induction of hypomagnesemia. Fecal examination, liver function, and kidney function tests were carried out for detection of any internal parasite, liver or kidney 
affections. Hypomagnesemia was induced by daily administration of potassium chloride (1.39 $\mathrm{gm} / \mathrm{kg}$ body weight) and citric acid ( $1.19 \mathrm{gm} / \mathrm{kg}$ body weight) orally by stomach tube till appearance of the characteristic signs of hypomagnesemia according to Hazarika and Pandey (1993); Hefnawy (2000) and Constable et al. (2017). Composition and analysis of the experimental and control ration is shown in table (1).

\section{b. Treatment trials}

Hypomagnesemic rams were divided into two groups according to the line of treatment. The first group $(n=5)$ was treated by the traditional treatment alone included injection $50 \mathrm{ml}$ of magnesium sulphate $20 \%$ $\mathrm{I} / \mathrm{V}, 50 \mathrm{ml}$ of magnesium sulphate $20 \% \mathrm{~S} / \mathrm{C}$, 25 gm of magnesium chloride orally and vitamin $\mathrm{AD} 3 \mathrm{E}$ in addition to calcium and dextrose 5\% I/V (Hefnawy 2000). For the second group $(n=5)$ the traditional treatment was applied in addition to L-carnitine (Lcarnitine $^{\circledR} 1 \mathrm{gm}$, MEPACO) $20 \mathrm{mg} / \mathrm{kg} \mathrm{I} / \mathrm{V}$ (Kaçar et al., 2010).

c. Sampling and biochemical analysis of sera

Blood samples were collected from rams before induction and after appearance of clinical signs of hypomagnesemia. Also, blood samples were collected at 6, 12 and 24 hours after treatment.

Blood samples were collected from jugular vein. The samples were allowed to clot in slanting position at room temperature for about 2 hours then the samples were centrifuged at $3000 \mathrm{rpm}$ for 10 minutes, the clear sera were aspirated carefully by automatic pipette and transferred into clear dry labeled Eppendorf tubes and stored at $-20{ }^{\circ} \mathrm{C}$ till examination. Only clear non-hemolyzed sera were used for the biochemical examination. Magnesium was determined spectrophotometrically by using special kits according to Fischbach and Dunning (2009). Calcium was determined according to Gindler and King (1972). Na and $\mathrm{K}$ were determined spectrophotometrically by using special kits according to Henry et al. (1974). Urea, creatinine and glucose were determined spectrophotometrically by using special kits according to the method described by Young (1990). Serum cortisol concentration was determined using an ELISA kit (Eucardio Laboratory, Inc., Encinitas, and CA., U.S.A.). PTH was determined by Radioimmunoassay (RIA) according to the method described by Mayar et al. (1979). CPK was determined spectrophotometrically by using special kits according to the method described by Rec. GSCC (1977). cTnI concentration was measured according to Collinson et al. (2001)

2.4. Statistical analysis

The obtained results from the experiments were expressed as mean \pm SEM and were analyzed using (SPSS Statistics for Windows, version 23.0. Armonk, NY: IBM Corp). Differences were declared significant when $(\mathrm{P}<0.05)$.

\section{Results}

\section{a. Clinical findings}

The symptoms of hypomagnesemia appear gradually until complete appearance of symptoms at day 28 post induction. These symptoms included loss of appetite, grinding on teeth, restlessness, spasmodic defecation and urination, arched back, tetany, and staggering gait, champing of the jaw with foamy salivation, opisthotonus, nystagmus and episodes of convulsions. The rectal temperature, pulse rate and respiration rate were increased. These symptoms were disappeared after both trials of treatment. However, in case of L-carnitine group, recovery was earlier and more pronounced at $24 \mathrm{hrs}$ after treatment. 
b. Biochemical findings

As shown in Table 2 and Figure 1, there were significant decrease $(\mathrm{P}<0.05)$ in serum $\mathrm{Mg}$, $\mathrm{Ca}$, glucose and $\mathrm{PTH}$ in hypomagnesemic rams. However, there were significant increase $(\mathrm{P}<0.05)$ in serum $\mathrm{Na}, \mathrm{K}$, urea, creatinine, cortisol, CPK and cTnI in experimentally induced hypomagnesemic rams after 28 days of induction.

By comparing the two lines of treatment, the results revealed that treatment of hypomagnesemia with traditional treatment and L-carnitine resulted in significant elevation $(\mathrm{P}<0.05)$ of serum $\mathrm{Mg}, \mathrm{Ca}$, glucose and PTH than traditional treatment alone after 24 hours of treatment. Additionally, there were significant decrease $(\mathrm{P}<0.05)$ in serum $\mathrm{K}$, urea, CPK and cTnI 24 hours after treatment with L-carnitine.

Table 1 Composition and analysis of the experimental ration

\begin{tabular}{ll|ll}
\hline Ingredients & $\%$ & Analysis of ingredients & $\%$ \\
\hline Grounded yellow corn & 47.6 & TDN & 69.95 \\
Soya bean meal & 14.7 & CP & 14 \\
Wheat bran & 18 & CF & 9.1 \\
Polished rice & 5 & Ca & 0.95 \\
Soya bean hulls & 10.9 & $\mathrm{P}$ & 0.40 \\
Grounded lime stone & 2.3 & $\mathrm{Na}$ & 0.42 \\
Sodium chloride & 0.5 & $\mathrm{CL}$ & 0.58 \\
Ammonium chloride & 0.5 & & \\
Premix vitamin and mineral & 0.3 & & \\
mixture & & & \\
Sodium bicarbonate & 0.2 & & \\
\end{tabular}


Helal et al.,2018, BVMJ, 35 (2) 31 - 43

Table 2 Biochemical findings in healthy, experimentally induced hypomagnesemic (Diseased) rams, traditional treatment alone and traditional treatment with L- carnitine (Means \pm SEM).

Values with different letters within the same column are significantly different at $\mathrm{P}<0.05$.

\begin{tabular}{|c|c|c|c|c|c|c|c|c|c|c|c|c|}
\hline & & $\begin{array}{c}\mathrm{Mg} \\
(\mathrm{mg} / \mathrm{dl})\end{array}$ & $\begin{array}{c}\mathrm{Ca} \\
(\mathrm{mg} / \mathrm{dl})\end{array}$ & $\begin{array}{c}\mathrm{Na} \\
(\mathrm{mEq} / \mathrm{L})\end{array}$ & $\begin{array}{c}\mathrm{K} \\
(\mathrm{mEq} / \mathrm{L})\end{array}$ & $\begin{array}{l}\text { Urea } \\
(\mathrm{mg} / \mathrm{dl})\end{array}$ & $\begin{array}{c}\text { Creatinine } \\
(\mathrm{mg} / \mathrm{dl})\end{array}$ & $\begin{array}{c}\text { Glucose } \\
\text { (mg/dl) }\end{array}$ & $\begin{array}{c}\text { Cortisol } \\
(\mathrm{U} / \mathrm{L})\end{array}$ & $\begin{array}{l}\text { PTH } \\
(\mathrm{U} / \mathrm{L})\end{array}$ & $\begin{array}{l}\text { CPK } \\
(\mathrm{U} / \mathrm{L})\end{array}$ & $\begin{array}{l}\text { cTnl } \\
(\mathrm{U} / \mathrm{L})\end{array}$ \\
\hline Healthy & & $2.5 \pm 0.1 \mathrm{a}$ & $10.1 \pm 0.2 a$ & $144.7 \pm 0.6 \mathrm{c}$ & $4.6 \pm 0.1 \mathrm{c}$ & $16.7 \pm 0.4 c$ & $0.7 \pm 0.0 c$ & $48.0 \pm 0.8 b$ & $4.2 \pm 0.2 b$ & $10.3 \pm 0.6 a$ & $68.8 \pm 2.8 c$ & $0.04 \pm 0.01 d$ \\
\hline Diseased & & $0.7 \pm 0.1 e$ & $7.5 \pm 0.3 d$ & $153.1 \pm 1.2 \mathrm{a}$ & $7.5 \pm 0.3 a$ & $25.2 \pm 1.1 \mathrm{a}$ & $1.6 \pm 0.1 \mathrm{a}$ & $36.3 \pm 2.2 \mathrm{c}$ & $7.2 \pm 0.5 a$ & $7.6 \pm 0.6 c$ & $92.3 \pm 1.6 a$ & $1.07 \pm 0.06 a$ \\
\hline \multicolumn{13}{|c|}{ Traditional treatment only } \\
\hline & $6 \mathrm{~h}$ & $1.4 \pm 0.2 d$ & $8.7 \pm 0.2 c$ & $151.0 \pm 1.5 b$ & $6.0 \pm 0.1 b$ & $21 \pm 0.6 b$ & $1.2 \pm 0.1 b$ & $44.0 \pm 0.6 b$ & $4.8 \pm 0.1 \mathrm{c}$ & $7.8 \pm 0.2 b$ & $80.3 \pm 1.2 b$ & $0.65 \pm 0.03 b$ \\
\hline & $12 \mathrm{~h}$ & $1.5 \pm 0.2 \mathrm{~d}$ & $9.0 \pm 0.1 b$ & $148.7 \pm 1.2 \mathrm{c}$ & $5.4 \pm 0.3 b$ & $18.7 \pm 0.9 b$ & $0.8 \pm 0.0 c$ & $46.0 \pm 0.6 b$ & $4.2 \pm 0.1 b$ & $8.3 \pm 0.2 b$ & $73.3 \pm 0.9 b$ & $0.44 \pm 0.07 b$ \\
\hline & $24 \mathrm{~h}$ & $1.8 \pm 0.1 \mathrm{c}$ & $9.2 \pm 0.0 \mathrm{~b}$ & $145.0 \pm 0.6 c$ & $5.1 \pm 0.2 b$ & $18.3 \pm 0.3 b$ & $0.7 \pm 0.0 c$ & $47.7 \pm 0.9 b$ & $3.7 \pm 0.1 b$ & $8.8 \pm 0.2 b$ & $72 \pm 2.5 b$ & $0.11 \pm 0.02 \mathrm{c}$ \\
\hline \multicolumn{13}{|c|}{ Traditional treatment ar } \\
\hline & $6 \mathrm{~h}$ & $1.8 \pm 0.1 \mathrm{c}$ & $8.9 \pm 0.5 c$ & $150.7 \pm 0.3 b$ & $6.2 \pm 0.4 b$ & $21.3 \pm 0.9 b$ & $1.1 \pm 0.1 \mathrm{c}$ & $45.7 \pm 0.3 b$ & $4.3 \pm 0.2 b$ & $7.6 \pm 0.3 c$ & $81.7 \pm 2.7 b$ & $0.6 \pm 0.06 b$ \\
\hline & $12 \mathrm{~h}$ & $2.1 \pm 0.1 b$ & $10.1 \pm 0.2 \mathrm{a}$ & $147.0 \pm 0.6 c$ & $5.4 \pm 0.5 b$ & $17.0 \pm 0.6 \mathrm{c}$ & $0.9 \pm 0.1 \mathrm{c}$ & $48 \pm 0.6 b$ & $3.4 \pm 0.2 \mathrm{c}$ & $9.0 \pm 0.6 b$ & $74.7 \pm 2 b$ & $0.21 \pm 0.05 c$ \\
\hline & $24 \mathrm{~h}$ & $2.4 \pm 0.2 a$ & $10.6 \pm 0.2 \mathrm{a}$ & $143.7 \pm 0.3 c$ & $4.5 \pm 0.2 c$ & $16.0 \pm 0.6 c$ & $0.7 \pm 0.1 \mathrm{c}$ & $53 \pm 0.6 a$ & $3.0 \pm 0.0 c$ & $9.9 \pm 0.6 a$ & $63.7 \pm 1.9 c$ & $0.05 \pm 0.01 d$ \\
\hline
\end{tabular}


Evaluation of L-carnitine in the treatment of experimentally induced hypomagnesemia in sheep
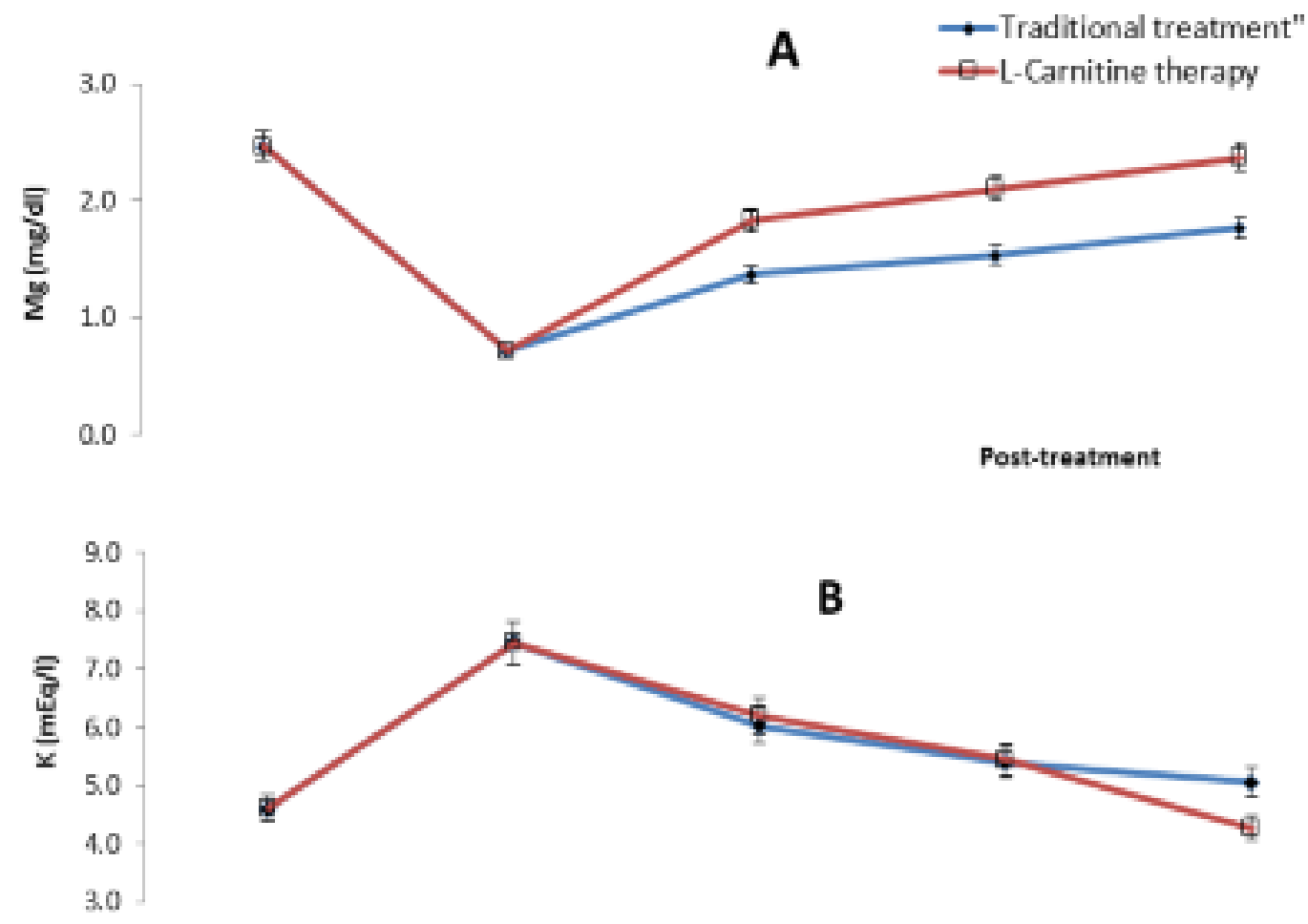

B
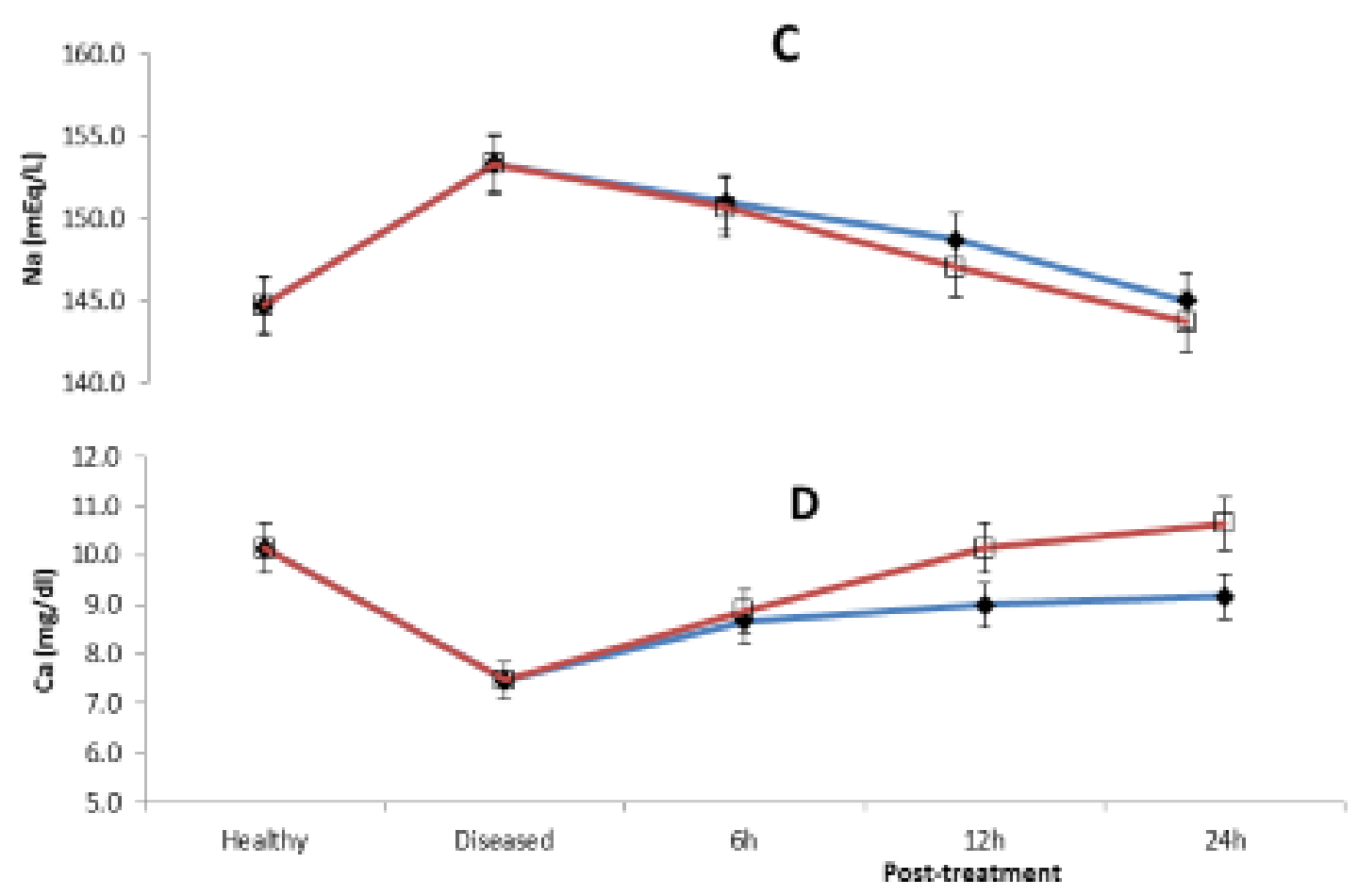

Figure 1a: $\mathrm{Mg}, \mathrm{k}, \mathrm{Na}$ and $\mathrm{Ca}$ serum levels in healthy, experimentaly induced hypomagnesemic (Diseased) rams, traditional treatment alone and traditional treatment with L- carnitine. 
Helal et al.,2018, BVMJ, 35 (2) 31 - 43
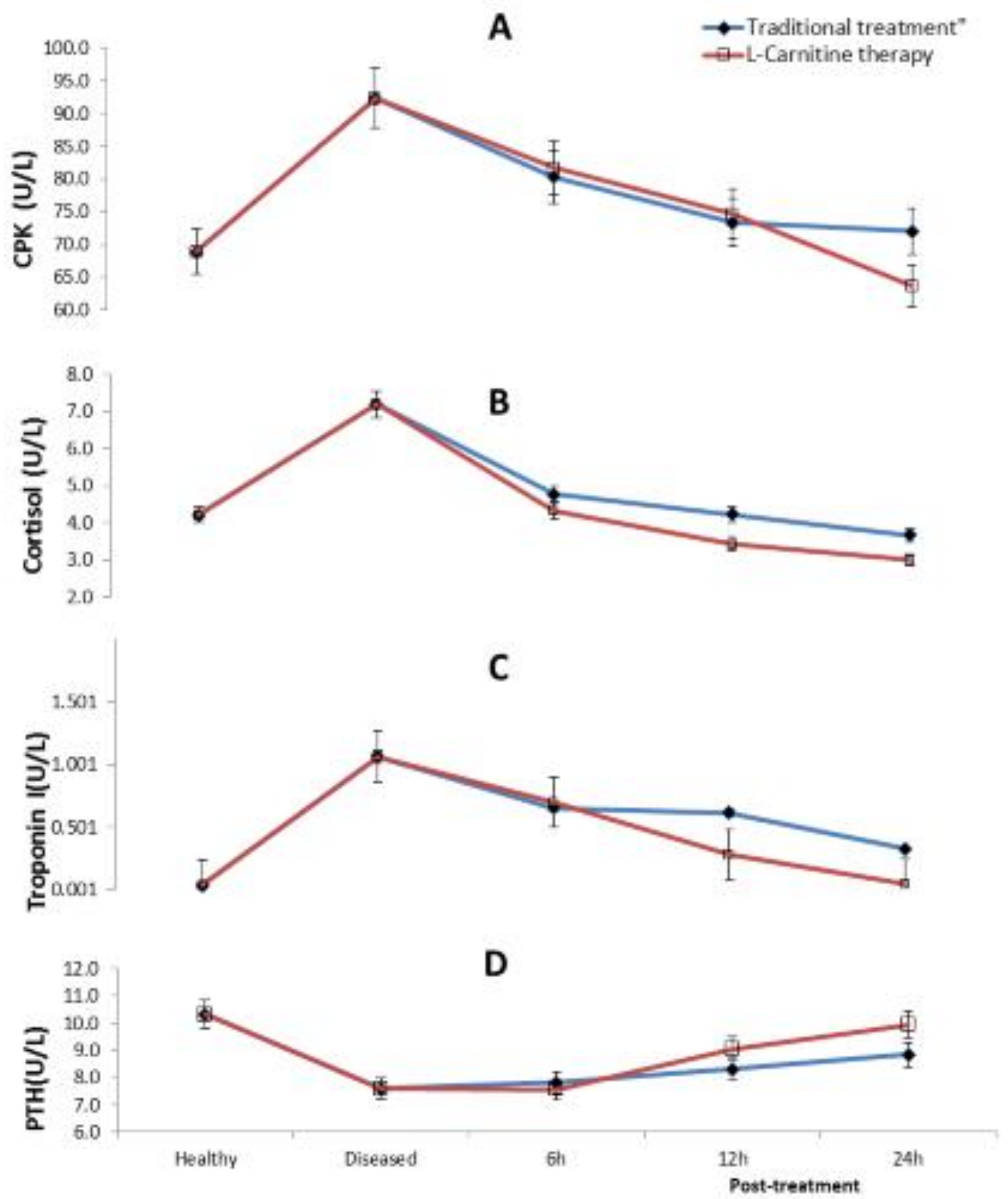

Figure 1b: CPK, cortisol, troponin I and PTH serum levels in healthy, experimentaly induced hypomagnesemic (Diseased) rams, traditional treatment alone and traditional treatment with L- carnitine. 
Evaluation of L-carnitine in the treatment of experimentally induced hypomagnesemia in sheep

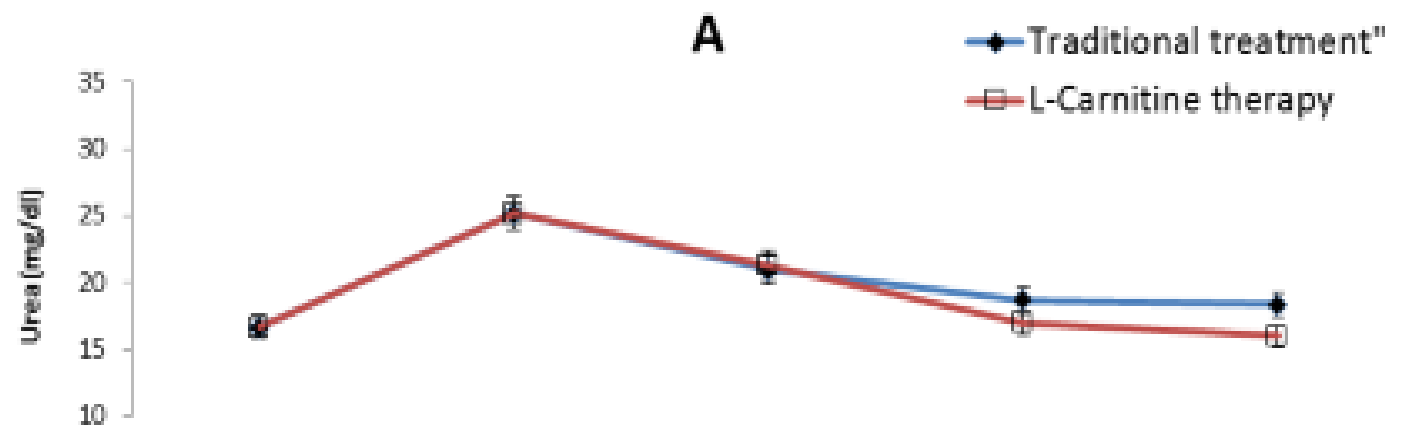

B
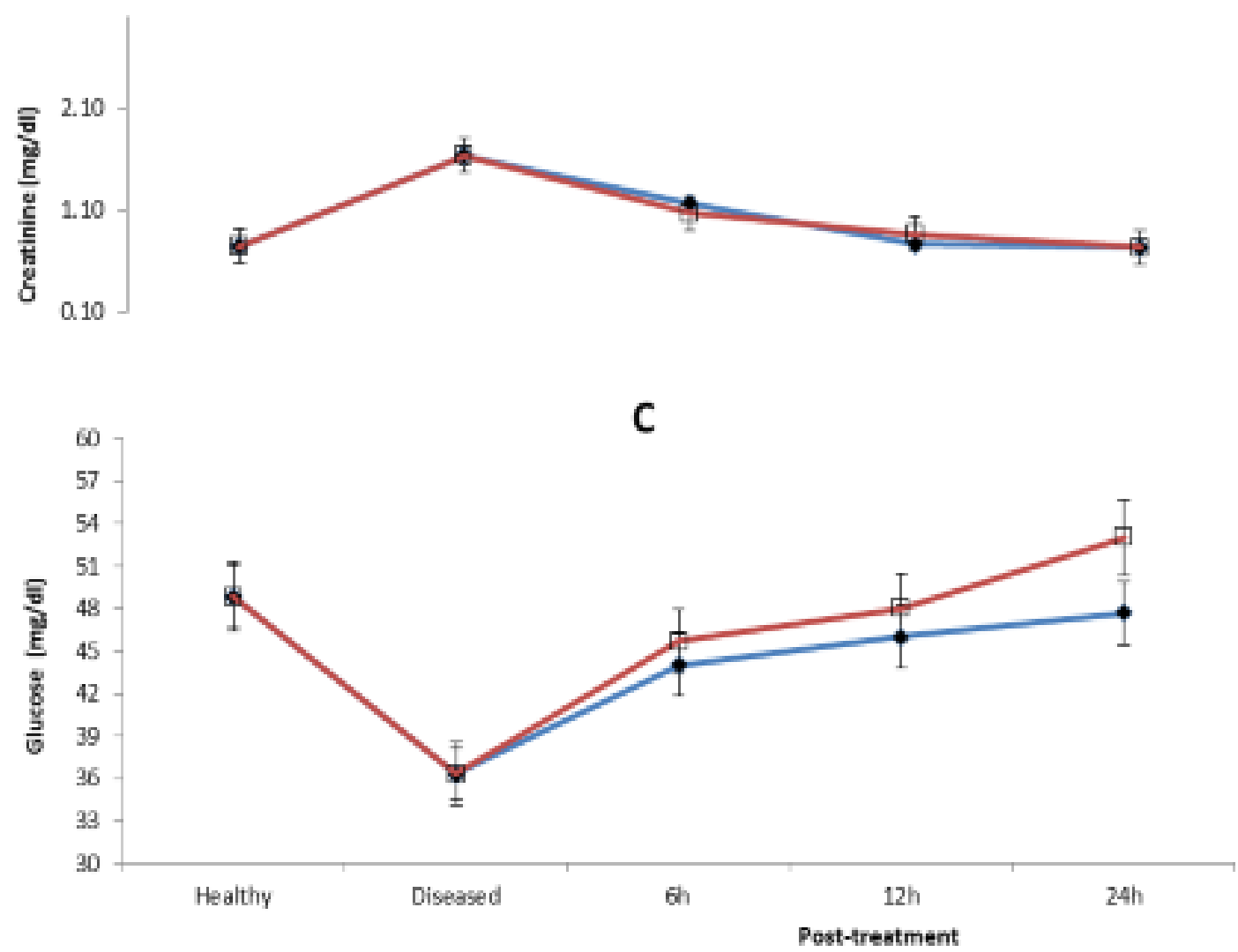

Figure 1c: Urea, creatinine and glucose serum levels in healthy, experimentaly induced hypomagnesemic (Diseased) rams, traditional treatment alone and traditional treatment with Lcarnitine. 


\section{Discussion}

$\mathrm{Mg}$ has been shown to be involved in several enzyme activities in the body, a major intracellular divalent cation and also associated with many physiological and biochemical functions (Constable et al., 2017).The diagnosis of clinical hypomagnesemic tetany is general made by a combination of history, clinical signs and response to treatment. Clinical signs rapidly progress to death (McCoy, 2004).

Clinical hypomagnesemia was induced experimentally in sheep in the current study after oral administration of $\mathrm{K}$ chloride and citric acid for 28 days which is consistent with findings of Hazarika and Pandey (1993), Hefnawy (2000) Abd El-Maksoud et al., 2012 and Constable et al., (2017). K ingestion by ruminants may be an enhancement of the urinary excretion of $\mathrm{Mg}$, the major effect on $\mathrm{Mg}$ metabolism is a substantial reduction of absorption of $\mathrm{Mg}$ from the reticulorumen (Tomas and Potter, 1976; Zelal, 2017)

Regarding the clinical symptoms of hypomagnesemia in sheep, as appearing gradually till 28 days post induction. Similar findings were recorded by Hefnawy( 2000) and constable et al. (2017). These signs appeared clearly when $\mathrm{Mg}$ level fall below 1 $\mathrm{mg} / \mathrm{dl}$ which was coincided with Kunkel et al. (1953) and Hefnawy (2000). Tetany does not occur until the serum magnesium falls below this concentration (Constable et al., 2017).

There was significant decrease in serum $\mathrm{Ca}$ in hypomagnesemic rams that was coincided with Foster et al. (2007), Haigney et al. (2007) Abd El-Maksoud et al. (2012) and Rani (2015) who reported that hypomagnesemia influences $\mathrm{Ca}$ metabolism by reducing the secretion of $\mathrm{PTH}$ in response to hypocalcaemia and reducing tissue sensitivity to PTH, particularly in bone, gut and kidney, which are all important for $\mathrm{Ca}$ absorption. There were significant increase in serum $\mathrm{Na}$ and $\mathrm{K}$ in hypomagnesemic rams which was coincided with Constable et al. (2017) who reported that ruminants grazing on high $\mathrm{K}$ pasture may result in depression of $\mathrm{Na}$ : $\mathrm{K}$ ratio in the rumen fluid which reduces the absorption of $\mathrm{Mg}$ in ewes. Similar to the present study, Ghanem (2013) also recorded significantly increased blood urea in hypomagnesaemic calves. Also, the significant decrease of glucose in the present study may be due to reduction of the food intake associated with hypomagnesaemia (Hazarika and Pandey 1993; Hoff et al., 1993; Attia, 1999; El-Sangary et al., 2011; Ghanem 2013 and Rani 2015). Moreover, Baig et al. (2012) attributed the decrease in serum glucose to the interrelationship between $\mathrm{Mg}$ and carbohydrate metabolism. The significant decrease of cortisol may be due to stress reaction involving the adrenal-glucocorticoid axis increased circulating $\mathrm{K}$ concentration and lowered $\mathrm{Mg}$ transport across the choroidal plexus, which was one of causes of this disease (Robson et al., 2004). There was significant increase in serum CPK that indicated muscular damage in hypomagnesemic rams This result was also supported by Ghanem (2013) and Constable et al., (2017). Significant increase in serum cTnI in the current study was in agreement with Kumar and Sagar (2013) and Celik et al. (2016) which may be associated with increased myocardial damage (Chang et al., 1985). Mg plays a role in controlling calcium entry into the cells, thus affecting the cardiac smooth muscle tone (Čvorišćec et al., 2009).

The traditional treatment of hypomagnesemia in ruminants includes administration of $\mathrm{Mg}$ and $\mathrm{Ca}$ salts, separately 
or as a combined solution (Foster et al., 2007; Elliott 2009; Ghanem 2013; Zelal 2017). In the present study, hypomagnesemic rams recovered completely within 24 hours after traditional treatment and L-carnitine. They resumed their appetite and biochemical profile to be around normal level. Findings of the present study are coincided with Pinsent and Cottom (1987) and Foster (2007) in small ruminants and Ghanem (2013) in calves.

Treatment of hypomagnesemic rams with traditional treatment and L-carnitine resulted in significant elevation of serum $\mathrm{Mg}$, $\mathrm{Ca}$ and PTH in experimentally induced hypomagnesemic rams than traditional treatment only. Haarenen (2003) and Mercadal et al.(2018) recorded that L-carnitine supplementation increased serum calcium concentration. The traditional treatment with L-carnitine resulted in significant elevation of serum glucose in hypomagnesemic rams than traditional treatment only which is coincided with the results of Kaçar et al., (2010) and Chapa et al., (2001). Giduck and fontenot (1987) and Baig et al. (2012) recorded that the increase in glucose increases absorption of $\mathrm{Mg}$. According to the results of the present study the positive effect of L-carnitine on serum magnesium could be attributed to Lcarnitine positive effect on both calcium and glucose.

There was significant decrease in serum urea with L-carnitine injectiont 24 hour after treatment. Similar finding was recorded by Mercadal et al. (2018). There was significant decrease in serum $\mathrm{K}$ in case of $\mathrm{L}$ carnitine treatment. This result was coincided with Laboni et al., (1987) who reported that Lcarnitine deficiency may play a major role in Na-K pump dysfunction in uremic patients. There was significant decrease in serum cortisol with L-carnitine injection which is agreed with Parnetti et al. (1990).

There were significant decrease in serum cTnI and CPK at 24 hours after treatment with L- carnitine. This result was in agreement with Sun et al., 2011 who recorded that serum level of myocardium injury marker (cTnI) returned to the normal levels after Lcarnitine administration. L-carnitine reduces the myocardial injury mainly through improving carbohydrate metabolism and reducing the toxicity of high levels of free fatty acids (Buerrner et al., 2006; Dinicolantonio et al., 2013). Additionally, Giamberardino et al. (1996) reported that Lcarnitine has a protective effect against pain and muscle damage and reduce serum CPK.

\section{Conclusion}

Based on the results of this study we concluded that the injection of L- carnitine with the traditional treatment of hypomagnesaemia in sheep was effective and produced earlier and more pronounced recovery than traditional treatment only.

\section{References}

Abd El-Maksoud, H.A.A.; Tahia, E. Ahmed and El-Kharadly, W.A. 2012.Biochemical alterations of experimentally induced hypomagnesaemia in male baladi goats. Benha Veterinary Medical Journal. 23(1): 19-25.

Attia, M.T. 1999. Some studies on hypomagnesemia in calves under natural and experimental conditions. M.V.Sc.; Thesis, Faculty of Veterinary Medicine, Zagazig University, Egypt. 
Baig, M.S.A., Shamshuddin, M., Mahadevappa, K.L., Attar, A.H., Shaikh, A.K. 2012. Serum Magnesium as a Marker of diabetic complications. Journal of Evolution of Medical and Dental Sciences. 1(3):119-23.

Buettner, R., Parhofer, K.G., Woenckhaus, M., Wrede, C.E., Kunz- Schughart, L.A., Schölmerich, J., et al. 2006. Defining high-fat-diet rat models:metabolic and molecular effects of different fat types. J. Mol. Endocrinol. 36(3): 485-501.

Celik, M., Koklu, M., Gusoy, E., Gungor, M., Yasar, S., Gormel, S., Yildirim, E., Yalcin, Gokoglan, Y., Yuksel, U. C., Kabul, H. K., Barcin, C. 2016. The serum calcium to magnesium ratio in patients with acute coronary syndrome .Acta Medica Mediterranea. 32: 691.

Chang, C., Varghese, P.J., Downey, J., Bloom, S.1985. Magnesium deficiency and myocardial infarct size in the dog. $\mathrm{J}$ Am Coll Cardiol.2 (1):280-289.

Chapa, A.M., Fernandez, J.M., White, T.W., Bunting, L.D., Gentry, L.R., Lovejoy, J.C., Owen, K.Q. 2001. Influence of dietary carnitine in growing sheep fed diets containing non-protein nitrogen. Small Ruminant Res. 40: 13-28

Chapa, A.M., Fernandez, J.M., Whtte, T.W., Bunting, L.D., Gentry, L.R., Ward, T.L., Blum, S.A. 1998. Influence of intravenous L-carnitine administration in sheep preceding an oral urea drench. J. Anim. Sci. 76:2930-2937.

Collinson, P.O., Boa, F.G., Gaze, D.C. 2001. Measurement of cardiac troponins. Ann. Clin. Biochem. 38:423-449.

Constable, P. , W. K., Done S ,Gruenberg,W. 2017. Veterinary medicine: A textbook of the diseases of cattle, sheep, pigs, goats and horses. 11th ed. Edinburgh, Scotland: WB Saunders Company. 399-434.

Čvorišćec, D., Čepelak, I., In. M, Čvorišćec, D., Čepelak, I. E. 2009. Štrausova medicinska biokemija. Zagreb. Medicinska naklada; (in Croatian): 79-81.

DiNicolantonio, J.J., Lavie, C.J., Fares, H., Menezes, A.R., O’Keefe, J.H. 2013. L-carnitine in the secondary prevention of cardiovascular disease:systematic review and metaanalysis. Mayo Clin Proc. 88(6): 544551.

Elliott, M. 2009. Grass tetany in cattle treatment and prevention. Primefact, 42(1):1-4

www.dpi.nsw.gov.au/primefacts, December 3, 2014.

El-Sangary, F.H.; El-Barawy, A.M.; Faris A., ElHamied, S.S.A. 2011. Hypomagnesemia in beef calves at its relation with parathyroid hormone level. Assiut Vet. Med. J. 57 (131): 300-311.

Fathi, E. , Farahzadi, R. 2014. Application of L-carnitine as nutritional supplement in veterinary medicine. Romanian Journal of Biochemistry .51(1):31-41.

Fischbach, F.T., Dunning, M.B. 2009: Manual of laboratory and diagnostic tests, $8^{\text {th }}$ ed.philadelphia:Lippincott wiliams and wilkins.

Foster, A., Livesey, C., Edwards, G. 2007. Magnesium disorders in ruminants, In Practice. 29: 534-539.

Ghanem, M.M. 2013.Comparative study on the clinical and subclinical hypomagnesemia in calves with 
evaluation of therapeutic response. The $\mathrm{XX}$ International Congress of Mediterranean Federation of Health and Production of Ruminants, Faculty of Veterinary Medicine, Assiut University, pp. 123-134.

Giamberardino, M., Dragani, L., Valente, R., Di-Lisa, F., Saggin, R.,

Vecchiet, L. 1996. Effects of prolonged L-carnitine administration on delayed muscle pain and $\mathrm{CK}$ release after eccentric effort. International Journal of Sports Medicine. 17(05): 320-324.

Giduck, S.A., Fontenot, J.P.1987. Utilization of magnesium and other macroelements in sheep supplemented with different kinds of readily fermentable carbohydrate. J. Dairy SCI. 69:2278.

Gindler, E. M., King, J. D. 1972. Rapid colorimetric determination of calcium in biologic fluids with methylthymol blue: American Journal of Clinical Pathology. 58: 376-382.

Grunes, D.L., Hutcheson, D.P., Horn, F.P. 1984. Mineral composition of wheat forage as related to metabolic disorders of ruminants. In Horn GW (ed): National Wheat Pasture Symposium. Oklahoma Agricultural Experimental Station Miscellaneous Publication.115: 99-113

Haigney, M., Berger, R., Schulman, S. 2007. Tissue magnesium level and arrythmia. J. Cardiology. 8: 980986.

Haarenen S. 2003. Does high plant feed magnesium and potassium protect healthy ruminants from atherosclerosis? A review. Pathophysiology, 10: 1-6.

Harmeyer, J., Schlumbohm, C. 1997. Die physiologischr Bedeutung von Lcarnitine und Effekte von Carnit, inzulagen bei Haustieren. In Proc. Vitamine und Zusatzstoffe in der Ernährung von Mensch und Tier. VI. Symposium, Jena/Thüringen. 42-61.

Harmeyer, J.2001. L-Carnitin. Grosstierpraksis, 2: 28-41.

Hazarika, G .C. and Pandey, N. N. 1993. Clinical and biochemical changes during experimental chronic hypomagnesemia in goats and its treatment.Ind.Vet.J.70: 247-250.

Hefnawy, A. 2000.Research study on Magnesium deficiency in goat. M.V. SC. Thesis, Zagazig univ. (Benha Branch).

Henry,R.F., Cannon, D.C., Winkelman., J.W.,Editors. 1974. Clinical chemistry principals and Technics $2^{\text {nd }} \mathrm{Ed}$.Harper and Roe,Hagerstown,MD.

Hoff, B., Rognmo, A. Havre, G., Morberg, H. 1993. Seasonal Hypomagnesemia in reindeer on Kautokeino winter pasture in Finnmark County, Norway. Rangifer. 13 (3): 133-136.

Kaçar C, Zonturlu AK, Karapehlivan M, Arı UÇ, Ögün M, Çitil M. 2010. The effects of L-carnitine administration on energy metabolism in pregnant Halep (Damascus) goats. Turk J Vet Anim Sci .34: 163-171.

Kumar, A., Sagar, S. 2013. Comparison of serum magnesium and TroponinT in acute coronary syndrome. Journal of Evolution of Medical and Dental Sciences. 2(30): 5565-5567.

Kunkel, H.O., K. H. Burns, Bennie J. Camp; A. 1953. Study of Sheep Fed High Levels of Potassium Bicarbonate with Particular Reference to Induced Hypomagnesaemia, Journal of Animal Scienc. 12 (3): 451-458. 
Labonia, W.D., Morelli, O.H. Jr, Gimenez, M.I., Freuler, P.V., Morelli O.H.1987.Effects of L-carnitine on sodium transport in erythrocytes from dialyzed uremic patients. Kidney Int.32 (5):754-9.

Mayer, G.P, Hurst, J.G, Barto, J.A., Keaton, J.A., Moor, M.P.1979.Effect of epinephrine on PTH hormone secretion in calves Endocrinology 104:1181-1187.

Mayland, H.F., Grunes, D.L., Lazar, V.A., 1976. Grass tetany hazard of cereal forages based upon chemical composition. Agron J. 68:665.

McCoy, M.M., 2004. Hypomagnesemia and new data on vitreous humour magnesium concentration as a postmortem marker in ruminants. Magnesium Research. 17 (2): 137-145

Mercadal, L., Tezenas du Montcel, S., Chonchol, M. B., Debure, A., Depreneuf, H., Servais, A., Prié, D. 2018. Effects of L-Carnitine on Mineral Metabolism in the Multicentre, Randomized, Double Blind, PlaceboControlled CARNIDIAL Trial. American Journal of Nephrology. 349356.

Parnetti, L., Gaiti, A., Mecocci, P., Gottfries, C. G., Santucci, C., Reboldi, G. P., Senin, U. 1990. Effect of Acetyl- LCarnitine on Serum Levels of Cortisol and Adrenocorticotropic Hormone and Its Clinical Effect in Patients with Senile Dementia of Alzheimer Type. Dement Geriatr Cogn Disord. 1:165168.

Pinsent, J., Cottom, D.S. 1987. Metabolic diseases of goats. Goat Vet. Soc. J., 8: 40-42. (Vet. Bull. Abstr., $58: 1580$ ).

Rani, P. 2015. Clinical studies on metabolic diseases in goats (capra hircus) M.V. Sc. Thesis Rajasthan University of
Veterinary \& Animal Sciences, Bikaner (Rajasthan) 334001

Rec. GSCC (DGKC). 1977. Recommendation of German Society of Clinical Chemistry. J Clin Chem Clin Biochem.15:255.

Robert A. S., William, C. E. 1988. Hypomagnesemic Tetany of Ruminants. Veterinary Clinics of North America: Food Animal Practice.4 (2):365-377.

Robson, A.B., Field, A.C., Sykes, A.R., et al. 1997. A model of magnesium metabolism in young sheep. Magnesium absorption and excretion. Br. J. Nutr. 78:975-92.

Schonewille, J. Th., Van't Klooster, A.Th., Wouterse,H. , Beynen, A.C. 2000. Time courses of plasma magnesium concentrations and urinary magnesium excretion in cows subjected to acute changes in potassium intake. Vet Quart. 22: 136-40

Sun, Z.J., Yang, C.B., Wang H., Li Y. 2011. The impact of L-carnitine administration on the serum level of myocardium injury markers in patients with acute carbon monoxide poisoning. Zhongguo Wei Zhong Bing Ji Jiu Yi Xue. 12:739-42.

Tomas, F.M., Potter, B.J. 1976. The effect and site of action of potassium upon magnesium absorption in sheep. Australian Journal of Agricultural Research. 27: 873-880

Young, D.S. 1990. Effect of drugs on clinical laboratory tests. Third edition, AACC press, Washingon, D.C.3:122-131

Zelal, A. 2017. Hypomagnesemia Tetany in Cattle. J. Adv. Dairy Res. 5:2. 